\title{
Collective unconscious mental state and female feticide in India
}

\author{
Harish Kumar Sharma \\ Head of Department, Department of Psychology, S. B. S. Govt. College, Kotkapura, Punjab, INDIA
}

Email address:

sharmaharish361@gmail.com; harish_sbs@yahoo.com

\section{To cite this article:}

Harish Kumar Sharma. Collective Unconscious Mental State and Female Feticide in India. Psychology and Behavioral Sciences. Vol. 2, No. 5, 2013, pp. 188-191. doi: 10.11648/j.pbs.20130205.13

\begin{abstract}
Normally every human behavior is linked to the individual mental state but some behaviors that involve large number of people can be explained with Collective mental State. This collective mental state is constructed on the basis of long historical experiences, so it is usually unconscious. Collective Unconscious is a concept given by Carl Jung. It refers to the retaining of ancestral experiences at unconscious which are transferred from one generation to other generation in a long course of life. Jung stated that it ranges from retaining passive record of historical experiences i.e. passive Repository the actual practical emergence in ground reality i.e. Active Substratum. The female feticide occurring at mass level in India seems to be a reflection of Substratum state of collective unconscious. It means the historical experiences that are retained in collective unconscious at passive repository unconscious state has acquired the active substratum state of collective unconscious. These experiences are specifically related to the invasions people experienced during medieval period. This link is strengthen when the female sex ratio in India is observed state wise. Female feticide is highest in North-West states and lowest in Southern states. It means that the active substratum state of collective unconscious is the strongest causative factor of female feticide in India.
\end{abstract}

Keywords: Collective Unconscious, Female Feticide, Mental State, Invasions, Ancestors, Sex Ratio, history, India

Psychological studies normally focus on the mental state at the individual level, but some human behaviors, such as female feticide in India, cannot be explained under this scope. In developing an explanation to female feticide, the focus should be placed on the collective mental state because the same mental state is held by a large number of people in India. However, not much work has been done with this perspective so, in this paper, a little effort is given to confirm the presence of a collective mental state at the unconscious level with special linkage to female feticide in India.

Female feticide is killing the female child during the fetal stage. This has become possible because of the availability of the sex identity test. Earlier, when these tests were not available, this genocide was in practice in the form of female infanticide. It means that this highly condemnable practice of killing a female child has been prevalent for a long time in India. But now, it becomes serious because its negative impacts are beginning to emerge as observed in the census of 2001 and 2011 in the form of a sex ratio imbalance against females.[16,17]. Kurian also stated that "The international experience indicates that as a society develops economically the sex ratio turns more favourable to women. Within India, however, this does not appear to hold good."

A continuous increase of this imbalance will result in other serious problems. Various social factors are held responsible for this behavior, in particular, economic condition and dowry system. These do not seem as causative but are the reinforcing factors. The actual cause determining this act in India is based on the mental state of the people. This mental state involves the attitude and mental set against the female child. This mental state is the main causative factor and, to understand the behavior, it is essential to search the nature of this mental state. The first important characteristic is that it is active on a large scale. It is not restricted to a particular individual, community, group, or society, but exists in the mind of people in India on a massive level. This can be verified by checking the sex ratio of census of 2001 and 2011. The female ratio is declining in all the states of India. Thus, it can be stated that the mental state against the female child exists at a collective level. It means a large number of people in India have collectively the same attitude or mental set against the female child. Here, we raise the question about the possibility of the presence of a mental state at a collective 
level. The presence of a mental state at a collective level was recognized by various psychologists under different concepts. Hilberg (1980) has given the concept Jewish Ghetto, that is, the state of mind of Jewish people at a collective level. Thus, the life of a community takes place at many levels: not only physical, social, economic, and political, but also psychological. Collective mental state is a quality of a group, and groups can emerge with seemingly a life of their own, and, it can be said, a mind of their own. Durkheim (1964: 8) stated that the currents of opinion within a society, which are highly variable in intensity, impel large numbers of people toward higher or lower rates of marriage, birth or suicide, so that the resulting statistics express the state of the group (l'âme collective), which has been translated into English as a certain state of the group mind but which could also be translated as a collective mental state. Freud (1950) also asserted the concept of the collective mind, which he saw as operating through mental processes just as it does in the mind of an individual.

Another important characteristic of this collective mental state is that it is unconscious and irrational. It is a wellknown fact that logic and reasoning takes place at a conscious level but if an impulse or idea or mental state is unconscious, then the rationality will disappear. That is why consciously people admit that female feticide is an act of insanity but the results show that, at a personal level, this may not be true. At least the rise in female feticide and the decreasing female sex ratio in the census of 2001 and 2011 confirm this state. Thus, it means that the collective mental state against the female child is unconscious, and conscious realization is not practically altering it. Le Bon (1960) presents a theory of collective mental functioning, based on collective memories, linked with thoughts and emotions by the mechanism of contagion, leading to group action as a community functions. Action will be augmented by greatly reduced intellectual capacity, increased suggestibility and fickleness, and modified morality, which can be greater or lesser than individual morality. Freud (1955: 75), taking Le Bon's concept of the psychological group, noted that a racial unconscious emerges, describing it as an archaic heritage of the human mind, which is unconscious, similar to Le Bon's description, to which must be added a repressed unconscious. It thus indicates that a collective mental state having an attitude against female child is unconscious. Conscious reasoning and logic cannot alter this state because it is unconscious and repressed. When a mental set is unconscious, intellectual thinking is inhibited, which can bring a large number of people in this practice of insanity and genocide. Durkheim (1964: 9) stated that a collective sentiment is extremely powerful, because of the "...special energy resident in its collective origin".

The above explanation thus pointed that a community or society can have a collective mental state. This collective mental state has a basic function of developing a coherence and unity in the society but can also cause insane actions. The sentiments and emotions attached with this mental state have the power and force to turn mental state reflection into action. This mental state is unconscious in nature and the person is not consciously aware about the underlying experiences that are the basic cause of origin of this mental state. It can be termed collective unconscious, a term given by the Carl Jung (1916). It is a part of the unconscious mind, shared by a society, humanity, and all life forms, that is, the product of ancestral experience, and contains such concepts as science, religion, and morality. James (1901) stated unconscious as secondary memory that consists of long term memory held indefinitely. Freud did not distinguish between an "individual psychology" and a "collective psychology," whereas Jung distinguished the collective unconscious from the personal unconscious particular to each human being.[15]. The collective unconscious is also known as "a reservoir of the experiences of our species." Jung's notion of the collective unconscious ranges from a passive repository that records the history of all human reactions to the world to an active substratum that is the ground out of which all reality emerges. The components of the collective unconscious were first said by Jung to be primordial or ancestral images and later archetypes that manifest in consciousness through images, strong affects, and behavioral patterns. When the energies of the collective unconscious break through into consciousness, consciousness itself is altered, and reactions vary from insanity to a significant reordering of major attitudes.

The explanation given by Jung about collective unconscious states that some memories of past experiences are retained in the unconscious, this can create one's attitude and determine the behavior. It means that some historical and ancestral experiences of people of India, which are highly unfavorable toward the female child, are retained in the unconscious. From these experiences, the present collective mental state emerged, which is responsible for female infanticide and feticide. The account of these experiences is present in the historical background. It is very difficult to trace the ancestral experiences of People that constructed the collective unconscious mental set against the female child, but the linkage can be established partially if it is related to the invasions in India during the medieval period. Bostock (2008), in his paper on collective memory, pointed that a methodology for uncovering collective memory has yet to be established and so remains at this stage speculative. However, there is much circumstantial evidence that it exists. The effort in this paper is also based on such circumstantial evidence.

Most of the invaders entered through the North-West frontier states of India with the objective of plundering the wealth, killing many people in their attacks. The available records show that the conquest of India through the North West route took place continuously by different invaders from 712 A.D to 1526 A.D, i.e. for 814 years. Invaders from Europe opted the sea route and entered through the South West and East ports, with the objective of controlling the market and business. However, these invaders later on established their reign by annexing different Indian states. 
These brief references indicate that as the maximum brutal invasions take place through North West frontier states, the people of these states have experienced the maximum atrocities which decline toward the South. [2,13,14,18]. Fear, anxiety, and insecurity must be high there, and to resist the invasions, they must have felt the need for male children. These memories and experiences are retained in the unconscious, and a collective mental set is created in them. Adelson (1996) stated that the Jewish intellectuals in the Nazi ghettos summoned up centuries of literature on Jewish persecution as they interpreted their own experience of the most extreme occurrence of genocide in human history.

Table 1. Female Sex Ratio in India as per 2001 \& 2011 Census (females per thousand males)

\begin{tabular}{|c|c|c|c|}
\hline \multirow{2}{*}{ State } & \multicolumn{2}{|c|}{$\begin{array}{c}\text { Sex Ratio in 0-6 age group }-2001 \\
\text { Census }\end{array}$} & \multirow{2}{*}{$\begin{array}{c}\begin{array}{c}\text { Differen } \\
\text { ce }\end{array} \\
2011- \\
2001 \\
\end{array}$} \\
\hline & 2001-Census & $\begin{array}{c}\text { 2011- } \\
\text { Census } \\
\end{array}$ & \\
\hline Punjab & 875 & 893 & 18 \\
\hline Haryana & 861 & 877 & 16 \\
\hline Rajasthan & 922 & 926 & 04 \\
\hline Delhi & 821 & 866 & 45 \\
\hline Uttar Pradesh & 898 & 908 & 10 \\
\hline Bihar & 921 & 916 & -05 \\
\hline West Bengal & 934 & 947 & 13 \\
\hline Orissa & 972 & 978 & 06 \\
\hline Madhya Pradesh & 920 & 930 & 10 \\
\hline Gujarat & 921 & 918 & -03 \\
\hline Maharashtra & 922 & 946 & 24 \\
\hline Andhra Pradesh & 978 & 992 & 14 \\
\hline Karnataka & 964 & 968 & 04 \\
\hline Kerala & 1058 & 1084 & 26 \\
\hline Tamil Nadu & 986 & 995 & 09 \\
\hline India & 933 & 940 & 07 \\
\hline
\end{tabular}

Source : Census $2001 \& 2011$

Table 2. Female Sex Ratio in Different Regions as per Census 2001 \& 2011 (females per thousand males)

\begin{tabular}{lccc}
\hline Regions & $\mathbf{2 0 0 1}$ & $\mathbf{2 0 1 1}$ & Average \\
\hline North-West & 883.2 & 902.6 & 892.9 \\
East & 942.3 & 947 & 944.6 \\
South & 996.5 & 1009.7 & 1003.1 \\
\hline
\end{tabular}

These experiences decline toward the South because the invasions were less in those states. It means even if the southern people may have an unfavorable attitude toward the female child, its intensity may be low. These experiences were retained in the memories of the ancestors of those periods, which were transferred to the next generations, and now its impact is observed in the form of female feticide in present times in India (Tables 1 and 2).
Le Bon (1960) observed that the unconscious phenomena preponderate in the functioning of the mind. This is also shared collectively as innumerable common characteristics are passed from generation to generation to form what he called "the genius of the race," and in another terminology, this could be called collective memory, including of course, unretrieved collective memory. Durkheim (1964: 9) stated that there is a social culture passed to individual members of society by socialization with collective and ancient beliefs and practices, or in other words, collective memory. Bostock (2008) proposed that the life of a community at a psychological level is reflected in its mental state whose influence affects all members of a community to a greater or lesser extent. This collective mental state will be influenced by memories, which can also be collective insofar as they are produced by common experiences. The store of positively valued memories has been called psychic capital, but there are also negatively valued memories or negative psychic capital.

It can now be concluded that the attitude that favors the male child and is against the female child is held by the people as a collective mental state at the unconscious level. This collective mental state was developed on the basis of ancient beliefs and the historical experiences especially in reference to the medieval period. These experiences are retained as a collective memory and are transferred from one generation to another. This unconscious mental state also has the power and energy to be turned into action, and thus, female feticide is in practice. The partial proof to confirm this conclusion is based on the circumstantial evidence that the female sex ratio is declining and its highest occurrence in the North West states and lowest occurrence in southern states in accordance to the invasions in India. The efforts done to change the psyche of people are not giving desirable results because the unconscious state reduces the intellectual reasoning. It is thus suggested that, in order to stop this practice, the mental state at the unconscious level should be altered.

It is difficult to make suggestion deliberately at unconscious level but it is not impossible. It is well known fact that the childhood experiences are retained in unconscious mind. If attitude against female feticide and in favor of female child developed during childhood, may give positive results. Another method of shaping unconscious mental state is sending the message at subthreshold level. It means delivering message to mind without its awareness. It is observed in some studies that if a message is conveyed at such a low stimulus value, that is below the threshold level directly received at subconscious or unconscious level. It means messages in favor of female child and against female feticide should be displayed at very low stimulus value which is below threshold level. It is also observed that such type of message can be given to a big group at the same time. Third way is by creating better social and environmental conditions, where a woman lives better life. 


\section{References}

[1] Adelson, Alan, (Ed.), (1996). The Diary of Dawid Sierakowiak, Five Notebooks from the Lodz Ghetto. (Trans. Kamil Turowski). London: Bloomsbury.

[2] Arora, A. C., Ancient History of India, Pradeep Publishers, Jalandhar. Pp. 20,23,24.

[3] Bostock, W. W. (2008). Collective Aspects of Mental State, Memory and Psychic Capital: Their Role in Coherent Functioning of a Community, Journal of Humanities and Social Sciences, Volume 2, Issue 1, University of Tasmania, Australia.

[4] Durkheim, E. (1964). The Division of Labor in Society, Free Press,pp.8,9 ISBN-10:0029078504; ISBN13:9780029078501

[5] Freud, Sigmund, (1950). Totem and Taboo, Some Points of Agreement between the Mental Lives of Savages and Neurotics. London: Routledge \& Kegan Paul. Pp. 157

[6] Freud, Sigmund, (1955). Beyond the Pleasure Principle, Group Psychology and Other Works. In. Standard Edition, XVIII (1920-1922). London: Hogarth. pp. 75.

[7] Hilberg, Raul, (1980). "The Ghetto as a Form of Government." ANNALS, AAPSS, July, 450.

[8] James, William, (1901). The Principles of Psychology. London: Macmillan. Ch.16.
[9] Jung, Carl Gustav. (1916). The Structure of the Unconscious, Coll. works, vol. VII, London: Routledge \& Kegan Paul. PP. 5 .

[10] Jung, Carl Gustav. (1959). The Archetype and Collective Unconscious, Princeton University Press (NJ). PP. 3$28,43,287$.

[11] Kurian, N. J. Widening Disparities in India, www.planningcommissiongov.in/reports/articles/ncsxna/art_ wide.pdf

[12] Le Bon, G., (1960). (First Published 1895). The Mind of the Crowd. New York: Viking.

[13] Lane-Poole, Stanley (1907). "Chapter IX: Tinur's Account of His Invasion". History of India. The Grolier Society. Full text at Google Books

[14] Muslim Invasions, www.indianmirror.com, (Retrieved on 1st November, 2013)

[15] Personal Unconscious vs. Collective Unconscious Freud vs. Jung, www.teachers.sduhsd.k12.ca.us/mcunningham/Carl\%20Jun g.pdf. Pp.1

[16] Registrar General of India (2001); 2001 census hand book.

[17] Registrar General of India (2011); 2011 census hand book.

[18] Sir H. M. Elliot (1869). "Chapter II, Tarikh Yamini or Kitabu-1 Yamini by Al Utbi". The History of India, as Told by Its Own Historians. The Muhammadan Period. Trubner and Co. pp. 14-52. 